\title{
Benthic macroinvertebrate and fish communities in Lake Huron are linked to submerged groundwater vents
}

\author{
T. Garrison Sanders Jr. ${ }^{1,4, *}$, Bopaiah A. Biddanda ${ }^{1}$, Craig A. Stricker ${ }^{2}$, \\ Stephen C. Nold ${ }^{3}$ \\ ${ }^{1}$ Annis Water Resources Institute, Grand Valley State University, 740 W. Shoreline Drive, Muskegon, Michigan 49441, USA \\ ${ }^{2}$ USGS Stable Isotope Laboratory, DFC, Building 21, MS 963, Denver, Colorado 80225, USA \\ ${ }^{3}$ University of Wisconsin-Stout, Department of Biology, 213 Jarvis Hall, Science Wing, Menomonie, Wisconsin 54751, USA
}

${ }^{4}$ Present address: Crooked River Watershed Council, 498 SE Lynn Blvd, Prineville, Oregon 97754, USA

\begin{abstract}
Groundwater can be an important source of nutrients and energy to aquatic ecosystems, but quantifying the inputs and biogeochemical importance remains challenging. A series of submerged groundwater vents in northern Lake Huron were examined to determine the linkage between groundwater nutrients and aquatic food webs. We collected samples of key food-web components from groundwater vent and reference habitats and analyzed them for ${ }^{13} \mathrm{C},{ }^{15} \mathrm{~N}$, and ${ }^{34} \mathrm{~S}$ isotopes. Dissolved inorganic carbon (DIC) in the groundwater was depleted in ${ }^{13} \mathrm{C}$, while aqueous sulfate was enriched in ${ }^{34} \mathrm{~S}$ (mean differences between groundwater and reference sites were $-3.9 \%$ and $+12.0 \%$, respectively). Benthic primary producers, macroinvertebrates, and benthivorous fish had significantly lower $\delta^{13} \mathrm{C}$ values in groundwater environments, and benthivorous fish were somewhat depleted $(-2.5 \%)$ in $\delta^{34} \mathrm{~S}$ at groundwater sites compared to reference sites. However, $\delta^{15} \mathrm{~N}$ values were not different between groundwater and reference sites, and pelagic components of the ecosystems (plankton and planktivorous and piscivorous fish) were similar in both $\delta^{13} \mathrm{C}$ and $\delta^{15} \mathrm{~N}$. These data suggest benthic metazoan communities surrounding groundwater vents are partially linked to groundwater-derived benthic primary production, while planktivorous and piscivorous communities not directly associated with the benthos do not rely on groundwater nutrients.
\end{abstract}

KEY WORDS: Stable isotopes · Submerged sinkholes · Groundwater · Food web · Lake Huron

Resale or republication not permitted without written consent of the publisher

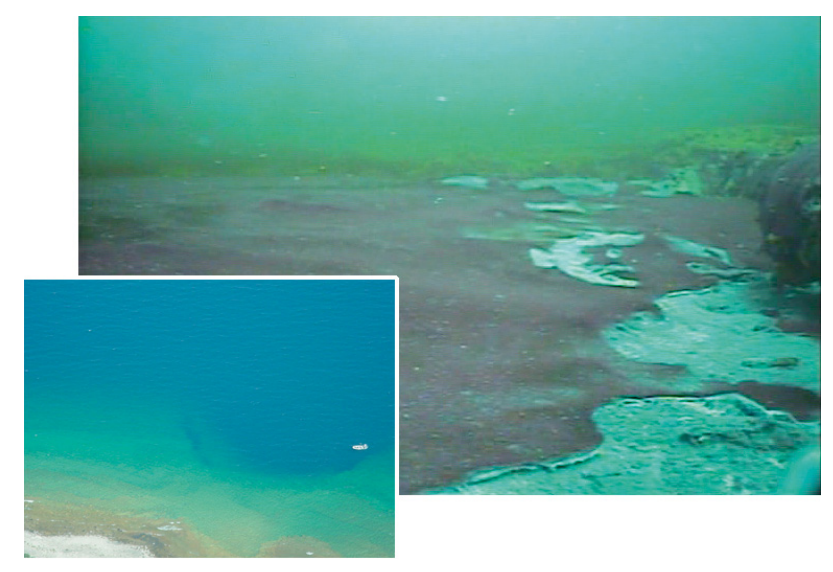

Underwater image showing purple cyanobacterial benthic mats thriving in a $2 \mathrm{~m}$ layer of dense sulfur-rich groundwater in Middle Island Sinkhole, Lake Huron (Inset, aerial photo of $100 \mathrm{~m}$ sinkhole with $7 \mathrm{~m}$ boat)

Photos: Rob Paddock, Scott Kendall (inset)

\section{INTRODUCTION}

A considerable amount of aquatic research has focused on the transport and uptake of terrestrial nutrients via runoff and river discharge (Valiela et al. 1990, Burnett et al. 2003). However, there is now increasing recognition that groundwater flow can also be an important source of nutrients and energy to aquatic ecosystems (Moore 2010). For example, the transport of nutrients via groundwater flow into nearshore marine waters is more significant and widespread than 
originally thought (Johannes 1980, Church 1996, Moore 1996, Burnett et al. 2003, Slomp \& Van Cappellan 2004, Moore et al. 2008). Although the flow rates may be limited in magnitude, submarine groundwater discharge (SGD) can carry increased concentrations of nutrients into the surrounding nearshore marine water (Capone \& Bautista 1985, Valiela et al. 1990, Slomp \& Van Cappellan 2004, Basterretxea et al. 2010). While there are fewer reports from freshwater habitats, sublacustrine groundwater discharge can also provide significant nutrient input into lakes when compared with nutrient input from streams (Loeb \& Goldman 1979, Brock et al. 1982, Hagerthey \& Kerfoot 1998, Shaw \& Prepas 1990).

Groundwater discharge is more prevalent in areas of high porosity, such as carbonate and evaporite terrains. These sediment materials are dissolved through chemical weathering to produce unique terrain features such as sinkholes and other karst topography (Jennings 1985). Groundwater flow through these dissolution conduits creates large aquifers in the carbonate bedrock, and sinkholes serve as the points of entry and exit to the groundwater system (Ford \& Williams 1989). On land, surface runoff collects inorganic nutrients from erosion/weathering and organic nutrients from decomposition, which can potentially enter the groundwater system.

Tracing nutrient flow through food webs to understand trophic relationships within ecosystems is a fundamental goal in ecology. Stable isotope analysis (SIA) provides a method to link biological production to nutrient sources and allows us to identify the important sources leading to the sustainability of food webs (Fry 2006). The use of stable isotopes to determine the sources and flow of nutrients has been successful in lentic (Estep \& Vigg 1985, Fry 1988, 1989, Hobson \& Welch 1992, Jones \& Waldron 2003), estuarine (Peterson et al. 1986, Peterson \& Howarth 1987, McClelland et al. 1997), and lotic (Hesslein et al. 1991, Hamilton et al. 1992) ecosystems. Nutrient sources of more specialized aquatic systems, such as deep sea vent communities, have also been examined using SIA (Kennicutt et al. 1992). Moreover, hydrologic research has shown differences in carbon (Atekwana \& Krishnamurthy 1998) and nitrogen (McClelland et al. 1997) isotope values of groundwater relative to surface waters. The applicability of stable isotope tracers in different ecosystems lends support to the possibility of tracing groundwater-derived nutrients to local aquatic vent communities. To date, this has not been performed in freshwater vent communities.

Since 2001, we have been studying the influence of SGD on the Lake Huron ecosystem. Dissolution of carbonate bedrock has produced karst features in the Lake Huron basin (Black 1983), with an extensive sys- tem of onshore sinkholes near Alpena, Michigan, and submerged sinkholes offshore in Lake Huron (Ruberg et al. 2005, 2008, Biddanda et al. 2006, 2009). This area is composed of Silurian-Devonian carbonate bedrock that contains an aquifer of limestone, shale, and sandstone matrix (Black 1983, Moreau 1983). The submerged sinkholes are sites of venting groundwater that is low in dissolved oxygen (DO), but high in inorganic ions (namely chloride $\left[\mathrm{Cl}^{-}\right]$, sulfate $\left[\mathrm{SO}_{4}{ }^{2-}\right]$, and ammonium $\left[\mathrm{NH}_{4}^{+}\right]$) (Biddanda et al. 2006, Ruberg et al. 2008). These environmental conditions cause the growth of large mats of bacteria and algae surrounding the groundwater vents that are different from surrounding lake communities (Nold et al. 2010a,b). However, little is known about the biological structure and function of groundwater vent ecosystems in the Great Lakes. Our objective was to trace inorganic nutrients from groundwater through primary producers into higher trophic levels (plankton, invertebrates, and fish) of the Lake Huron ecosystem using stable isotopes of C, N, and S. We hypothesized that isotopic differences between groundwater and ambient lake water would create distinct source isotope pools that would allow us to trace and evaluate the importance of groundwater nutrient subsidies on the benthic and pelagic communities surrounding the vents.

\section{MATERIALS AND METHODS}

Study area. We sampled food-web components from 4 sites in Lake Huron, northeast of Alpena, Michigan (Fig. 1). The study was conducted from May to August 2007 and 2008 at 2 sampling sites: a shallow (1 to $3 \mathrm{~m}$ ) spring in the El Cajon embayment $(600 \times 150 \mathrm{~m})$ along the coast of Lake Huron (17N 0317083 m E, $4994904 \mathrm{~m}$ $\mathrm{N}$ [UTM notation]) and a deeper (14 to $23 \mathrm{~m})$, bowlshaped collapse $(100 \times 150 \mathrm{~m})$ offshore along the northeastern edge of Middle Island in Lake Huron (17N $0317208 \mathrm{~m} \mathrm{E}, 5007627 \mathrm{~m} \mathrm{~N}$ ) (Fig. 1; Biddanda et al. 2009). Groundwater at the shallow site mixes quickly with surrounding oxic waters; mixing at the deeper groundwater site is limited due to thermo-, pycno-, and chemoclines.

Isotopic data from the groundwater sites were compared to reference sites that were similar in depth, but lacked groundwater input. To determine the absence of groundwater input at the reference sites, we measured specific conductance $\left(\mathrm{mS} \mathrm{cm}^{-1}\right)$ and based our decision on data from past studies (Ruberg et al. 2005, Biddanda et al. 2006) that showed groundwater in the area to have specific conductance values ranging from 1.8 to $2.5 \mathrm{mS} \mathrm{cm}^{-1}$, while lake water ranged from approx. 0.2 to $0.4 \mathrm{mS} \mathrm{cm}^{-1}$. Two reference sites were identified: Squaw Bay, a shallow (1 to $2 \mathrm{~m}$ depth) 
embayment south of Alpena (17N $0306454 \mathrm{~m} \mathrm{E}$, $4986394 \mathrm{~m} \mathrm{~N}$ ), and an offshore area (25 to $26 \mathrm{~m}$ depth) approximately $3.5 \mathrm{~km}$ northwest of Middle Island (17N $0317736 \mathrm{~m} \mathrm{E}, 5007412 \mathrm{~m} \mathrm{~N}$ ) (Fig. 1).

Field sampling. We collected 51 water samples from each site using Niskin bottle samplers. At the shallow sites, we collected water from a kayak to prevent perturbation of sediments; water was collected by SCUBA divers at the deeper sites. Groundwater samples were collected directly from the vents. At the reference sites, water was collected $<1 \mathrm{~m}$ from the bottom to ensure that the samples were taken at similar depth.

Bulk vegetation samples ( 100 g) were collected by hand from within the groundwater-impacted zone and from within the local area at our reference sites. Benthic producers were separated in the field by color and morphology, as previous work indicated distinct lineages based on color differences: purple filamentous cyanobacteria, whitish strands of sulfur-oxidizing bacteria (Beggiatoa spp.), and green photosynthetic benthic algae (Ruberg et al. 2008, Biddanda et al. 2009, Nold et al. 2010a, 2010b). For macrophytic vegetation, we made a visual estimate of relative abundance and collected samples from the dominant vegetation types. Phytoplankton and zooplankton samples were col- lected from water overlying the sinkhole sites and throughout the water column of the reference sites using a $20 \mu \mathrm{m}$ Nitex plankton net with a $20.3 \mathrm{~cm}$ mouth (Wildlife Supply); offshore sites were sampled with a vertical plankton tow, while shallow sites were sampled with discrete water samples filtered through a plankton net. We filtered plankton tow samples through a $112 \mu \mathrm{m}$ screen and retained both the filtrate and the remaining coarser fraction. With the bulk of seston and microbes likely to have passed through the $20 \mu \mathrm{m}$ plankton net, we assumed the $>20$ to $<112 \mu \mathrm{m}$ filtrate fraction consisted of phytoplankton cells and the $>112 \mu \mathrm{m}$ coarser fraction consisted of zooplankton.

We collected macroinvertebrates using HesterDendy samplers (APHA 1996). Hester-Dendy samplers were placed in the center of the sampling area at each site above the bottom sediment, but in the groundwater plume, and were left in the field for approximately $40 \mathrm{~d}$. Macroinvertebrates from each Hester-Dendy sampler were pooled before analysis to obtain stable isotope values for the entire macroinvertebrate community.

We collected fish using gillnets and minnow traps. The minnow traps had $0.3 \mathrm{~cm}$ mesh and a $2.5 \mathrm{~cm}$ diameter mouth. Gillnets were $38.1 \mathrm{~m}$ long experimental gillnets with $6.8 \mathrm{~m}$ high panels of increasing mesh size:

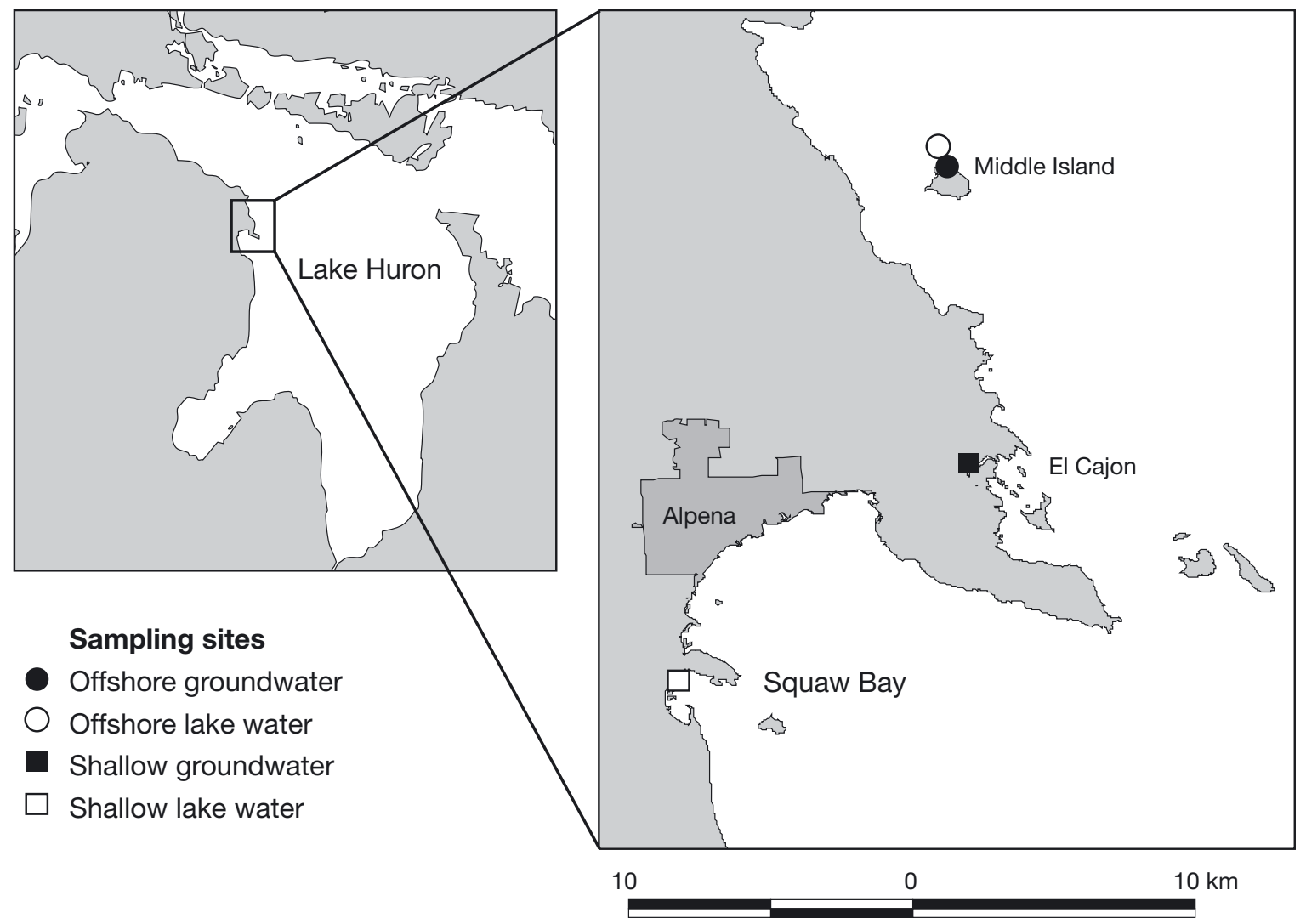

Fig. 1. Locations of shallow and offshore groundwater and reference study sites in the Thunder Bay National Marine Sanctuary near Alpena, Michigan. Lake water sites are reference sites 
$1.3,2.5,3.8,4.1$, and $5.4 \mathrm{~cm}$ bar measure monofilament mesh. Both minnow traps and gillnets were set on the lake bottom for 5 to $18 \mathrm{~h}$ during both the day and night to obtain a representative sample. Approximately $100 \mathrm{~g}$ of muscle tissue was taken from just behind the dorsal fin and above the vertebral column (Keough et al. 1996, Carabel et al. 2006) from fish larger than $9.0 \mathrm{~cm}$. Fish smaller than $9.0 \mathrm{~cm}$ were analyzed whole. All tissue samples were frozen for subsequent laboratory analysis.

Laboratory analysis. A $40 \mathrm{ml}$ aliquot of each water sample was retained for SIA of aqueous dissolved inorganic carbon (DIC), which was performed by the University of Utah Stable Isotope Ratio Facility for Environmental Research. Water samples were filtered onto $0.45 \mu \mathrm{m}$ Whatman GF/F filters to collect particulate organic matter (POM, representing all seston components), which were dried at $60^{\circ} \mathrm{C}$ for $48 \mathrm{~h}$, acidified with $1 \mathrm{M} \mathrm{HCl}$ to remove carbonates, and re-dried at $60^{\circ} \mathrm{C}$ for $12 \mathrm{~h}$. Organic matter samples were coarsely homogenized and dried at $60^{\circ} \mathrm{C}$ for $48 \mathrm{~h}$, or until completely dry. After drying, all samples except fish dorsal muscle tissue were acidified with $1 \mathrm{M} \mathrm{HCl}$ and dried again at $60^{\circ} \mathrm{C}$ for $12 \mathrm{~h}$. Animal tissues were lipid extracted for $7 \mathrm{~h}$ using a Soxhlet apparatus and an azeotropic mixture of chloroform and methanol (87:13) to obtain a more accurate determination of ${ }^{13} \mathrm{C}$ content (Sweeting et al. 2006). Organic samples were finely homogenized, loaded into tin capsules, and analyzed for $\mathrm{C}$ and $\mathrm{N}$ stable isotopes $\left({ }^{13} \mathrm{C} /{ }^{12} \mathrm{C} ; \delta^{13} \mathrm{C}\right.$ and ${ }^{15} \mathrm{~N} /{ }^{14} \mathrm{~N}$; $\delta^{15} \mathrm{~N}$ ) by continuous flow-isotope ratio mass spectrometry following standard procedures at the Michigan State University Biogeochemistry and Paleoproteomics Laboratory.

For isotopic analysis of sulfate-derived dissolved inorganic sulfur (DIS; levels of hydrogen sulfide were undetectable in groundwater, whereas concentrations of sulfate were around $1 \mathrm{~g} \mathrm{l}^{-1}$; Ruberg et al. 2008, Biddanda et al. 2009), water samples were fixed with mercuric chloride and sealed in either $125 \mathrm{ml}$ (groundwater) or $500 \mathrm{ml}$ (lake water) airtight conical-capped glass bottles. Splits of prepared fish samples were analyzed for stable sulfur isotopes $\left({ }^{34} \mathrm{~S} /{ }^{32} \mathrm{~S} ; \delta^{34} \mathrm{~S}\right)$. Approximately $5 \mathrm{mg}$ of fish material was mixed with $1 \mathrm{mg}$ of vanadium pentoxide and sealed into $4 \times 6 \mathrm{~mm}$ tin capsules. All ${ }^{34} \mathrm{~S}$ analyses were performed by the United States Geological Survey Stable Isotope Laboratory in Denver, Colorado.

Stable isotope notation. The ratio of stable isotopes is expressed in delta $(\delta)$ notation:

$$
\delta=\left[\left(R_{\text {sample }} / R_{\text {standard }}\right)-1\right] \times 1000
$$

where $\delta$ is the isotope ratio of the sample relative to a standard and $R_{\text {sample }}$ and $R_{\text {standard }}$ are the ratios of heavy to light isotopes in the sample and standard, respec- tively. Stable isotope data were normalized to the respective international standards for $\mathrm{C}, \mathrm{N}$ and $\mathrm{S}$ : Vienna Pee Dee Belemnite (VPDB), atmospheric nitrogen (air), and Vienna Canyon Diablo Troilite (VCDT), respectively.

Data analysis. To analyze food-web differences, we compared mean isotope values for each trophic level between our groundwater and reference sites using Student's or Mann-Whitney $t$-tests after assessing normality and equality of variances. We grouped fish into feeding groups (benthivorous, planktivorous, piscivorous) based on information from regional compilations (e.g. Hubbs \& Lagler 2007) and life histories. These statistical analyses were conducted using SPSS v. 14.0. We also analyzed the proportion of various nutrient sources to the benthic macroinvertebrate and benthivorous fish compartments of the food web at the groundwater sites using the IsoError (Phillips \& Gregg 2001) and IsoSource (Phillips \& Gregg 2003) stable isotope mixing model software developed by the Environmental Protection Agency, Western Ecology Division (www.epa.gov/wed/pages/models/stableIsotopes/ isotopes.htm).

\section{RESULTS}

We collected 126 samples for stable isotope analysis, 69 from the groundwater sites and 57 from the reference sites (Table 1). Sample sizes varied based on differences in primary producer and fish species distributions among sites. Groundwater and reference sites appeared similar in macroinvertebrate and fish community composition and typical of shallow wetlands and offshore ecosystems of the Great Lakes.

The mean $\delta^{13} \mathrm{C}$-DIC was lower in the groundwater $(-3.35 \pm 1.06 \%$, $\mathrm{n}=2)$ compared to the lake water $(0.55 \pm 0.50 \%, n=2)$, although not statistically significant ( $\mathrm{p}=0.121$, non-parametric Mann-Whitney). These differences in isotopic content were reflected in the food webs of the respective ecosystems. Benthic algal and bacterial mats were lower in $\delta^{13} \mathrm{C}$ (mean difference of $9.4 \%$ ) at groundwater sites relative to the reference sites, while macrophyte vegetation from the shallow groundwater site was slightly lower in $\delta^{13} \mathrm{C}$ $(5.2 \%$ ) compared to the shallow reference site (Table 1$)$. Although not an ideal comparison because of the possible $\delta^{13} \mathrm{C}$ contribution from epiphytes and because epiphytes are an important food base, it is quite difficult to obtain clean samples from aquatic vegetation, so emergent plants were used as a proxy for comparison. The benthic consumers (macroinvertebrates and benthivorous fish) from the groundwater systems followed a similar trend, with significantly lower $\delta^{13} \mathrm{C}$ values compared to reference ecosystems (Table 2). The 
Table 1. Mean, range, and sample size of $\delta^{13} \mathrm{C}, \delta^{15} \mathrm{~N}$, and $\delta^{34} \mathrm{~S}$ values for all components of the groundwater and reference (lake water) sites of sampling areas in Lake Huron. DIC: dissolved inorganic carbon from water samples; DIS: dissolved inorganic sulfur from water samples; POM: particulate organic matter; nd: not determined

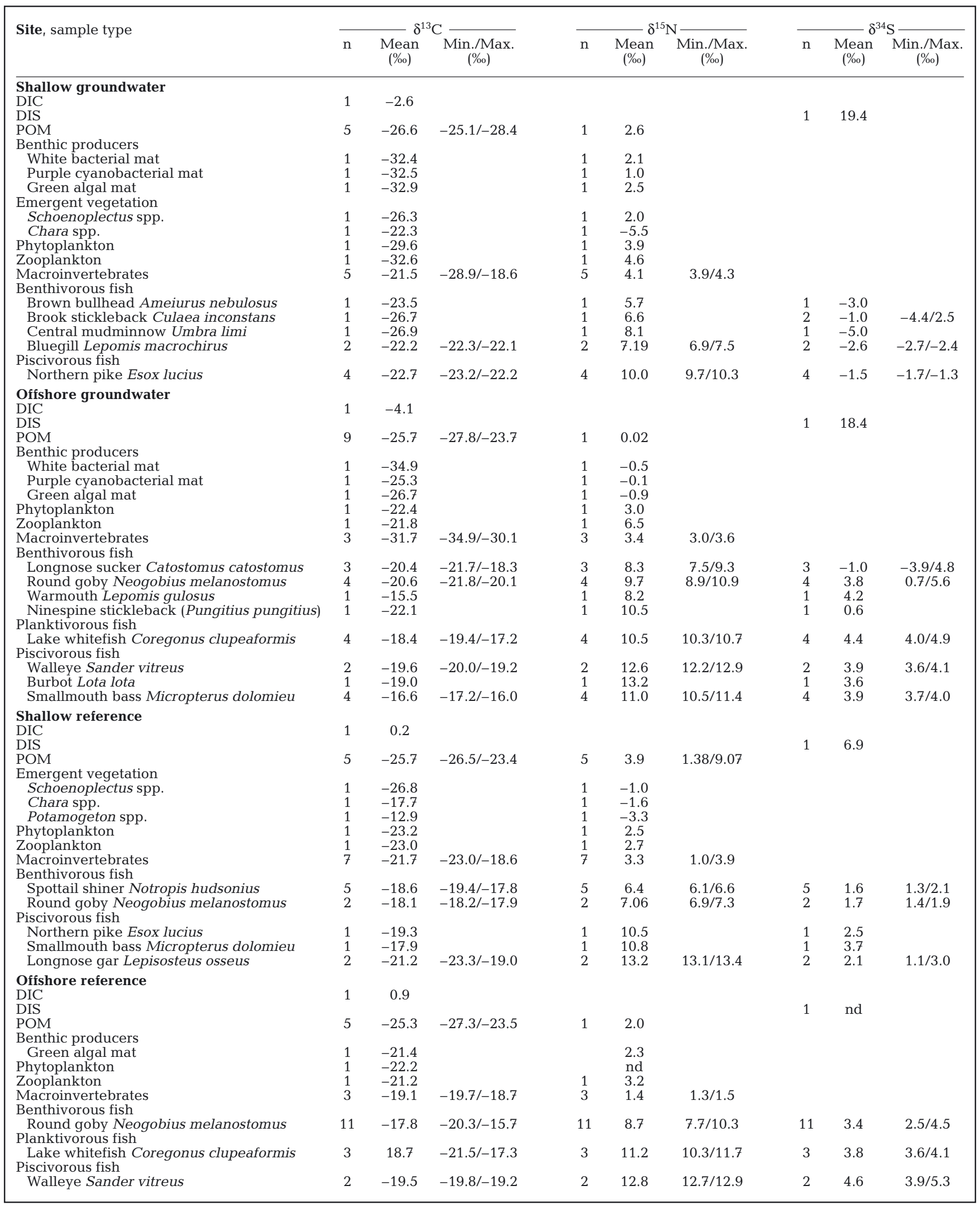


Table 2. Mean $( \pm \mathrm{SD}) \delta^{13} \mathrm{C}, \delta^{15} \mathrm{~N}$, and $\delta^{34} \mathrm{~S}$ values of different trophic levels at reference (lake water) and groundwater sites (sample size in parentheses), and associated p-values from independent $t$-tests. POM: particulate organic matter; ${ }^{*}$ : statistical significance at the $\alpha<0.10$ level

\begin{tabular}{|c|c|c|c|c|c|c|c|c|c|}
\hline \multirow[t]{2}{*}{ Trophic group } & \multicolumn{3}{|c|}{$\delta^{13} \mathrm{C}$} & \multicolumn{3}{|c|}{$-\delta^{15} \mathrm{~N}$} & \multirow[b]{2}{*}{$\begin{array}{c}\text { Reference } \\
(\%)\end{array}$} & \multirow{2}{*}{$\begin{array}{c}\delta^{34} \mathrm{~S}- \\
\text { Groundwater } \\
(\%)\end{array}$} & \multirow[b]{2}{*}{$\mathrm{p}$} \\
\hline & $\begin{array}{c}\text { Reference } \\
(\%)\end{array}$ & $\begin{array}{c}\text { Groundwater } \\
(\%)\end{array}$ & $\mathrm{p}$ & $\begin{array}{c}\text { Reference } \\
(\%)\end{array}$ & $\begin{array}{c}\text { Groundwater } \\
(\%)\end{array}$ & $\mathrm{p}$ & & & \\
\hline POM & $-25.5 \pm 1.3(10)$ & $-26.1 \pm 1.2(14)$ & 0.297 & $3.6 \pm 2.8(6)$ & $1.3 \pm 1.8(2)$ & $0.317^{\mathrm{a}}$ & & & \\
\hline $\begin{array}{l}\text { Producers } \\
\text { (macrophytes, } \\
\text { benthic mats) }\end{array}$ & $-19.7 \pm 5.9(4)$ & $-29.2 \pm 4.6(8)$ & $0.011^{*}$ & $-0.9 \pm 2.4$ & $0.1 \pm 2.6(8)$ & $0.308^{\mathrm{a}}$ & & & \\
\hline Phytoplankton & $-22.7 \pm 0.7(2)$ & $-26.0 \pm 5.1(2)$ & $0.439^{\mathrm{a}}$ & $2.5 \pm 0.0(1)$ & $3.5 \pm 0.6(2)$ & $0.221^{\mathrm{a}}$ & & & \\
\hline Zooplankton & $-22.1 \pm 1.3(2)$ & $-27.2 \pm 7.6(2)$ & $0.439^{\mathrm{a}}$ & $3.0 \pm 0.35(2)$ & $5.5 \pm(1.3)$ & $0.121^{\mathrm{a}}$ & & & \\
\hline Macroinvertebrates & $-20.9 \pm 2.0(9)$ & $-25.3 \pm 6.4(8)$ & $0.096^{*}$ & $2.7 \pm 1.3(9)$ & $3.8 \pm 0.5(8)$ & $0.016^{*, \mathrm{a}}$ & & & \\
\hline Benthivorous fish & $-18.1 \pm 1.4(18)$ & $-21.6 \pm 3.1(13)$ & $0.001^{*}$ & $7.8 \pm 1.3(18)$ & $8.2 \pm 1.4(13)$ & 0.452 & $2.7 \pm 1.1(18)$ & $0.2 \pm 4.0(14)$ & $0.014^{*}$ \\
\hline Planktivorous fish & $-18.7 \pm 2.4(3)$ & $-19.1 \pm 1.9(5)$ & $0.655^{\mathrm{a}}$ & $11.1 \pm 0.7(3)$ & $10.5 \pm 0.2(5)$ & $0.230^{\mathrm{a}}$ & $3.8 \pm 0.3(3)$ & $3.6 \pm 1.7(5)$ & $0.368^{\mathrm{a}}$ \\
\hline Piscivorous fish & $-19.8 \pm 1.9(6)$ & $-19.6 \pm 2.8(11)$ & 0.868 & $12.2 \pm 1.3(6)$ & $11.1 \pm 1.2(11)$ & $0.090^{*}$ & $3.3 \pm 1.4(6)$ & $1.9 \pm 2.7(11)$ & 0.195 \\
\hline
\end{tabular}

$\delta^{13} \mathrm{C}$ of macroinvertebrates at groundwater sites was lower $(4.4 \%$ ) than that at reference sites; groundwater benthivorous fish were, on average, $3.5 \%$ lower than at reference sites.

Except for the shallow groundwater site, the pelagic food-web components did not exhibit significant differences in $\delta^{13} \mathrm{C}$ values (Table 2). Phytoplankton and zooplankton $\delta^{13} \mathrm{C}$ from the shallow groundwater site were 6.4 and $9.0 \%$ lower than those from the shallow reference site, although there were negligible differences $(\sim 1.0 \%)$ in phytoplankton and zooplankton at offshore sites. Furthermore, planktivorous and piscivorous fish also showed little difference in isotope values between groundwater and reference sites (Table 2). In general, there were larger differences in $\delta^{13} \mathrm{C}$ values between the shallow sites and the offshore sites (Table 1).

The differences in $\delta^{15} \mathrm{~N}$ values between groundwater and reference sites ranged from $0.8 \%$ o (benthivorous fish) to $2.5 \%$ o (zooplankton), although macroinvertebrates and piscivorous fish were the only trophic groups to show significant differences (Table 2). However, both groundwater and lake-water food webs showed a positive enrichment in $\delta^{15} \mathrm{~N}$ in succeeding trophic levels. The average $\delta^{15} \mathrm{~N}$ trophic enrichment across trophic levels at all sites was 3.5\% per trophic level, although the range was quite variable (0.5 to $8.2 \%$ ).

The available $\delta^{34} \mathrm{~S}$ data also show clear differences in $\delta^{34} \mathrm{~S}$ between groundwater $(18.9 \pm 0.71 \%, \mathrm{n}=2)$ and lake-water $(6.9 \pm 0.0 \%, \mathrm{n}=1)$ systems. Groundwater was $12.0 \%$ higher than lake water, although sample size precluded the use of statistical tests. The $\delta^{34} \mathrm{~S}$ of benthivorous fish was also significantly different between the groundwater and reference sites. In contrast to the $\delta^{34} \mathrm{~S}$-DIS results, benthivorous groundwater fish were isotopically lighter than those from reference sites (Table 2). Similar to the $\delta^{13} \mathrm{C}$ data, there were no significant differences in $\delta^{34} \mathrm{~S}$ of either the planktivorous or piscivorous fish.

In general, benthic food-web components displayed distinct isotopic signatures $\left(\delta^{13} \mathrm{C}\right.$ and $\left.\delta^{15} \mathrm{~N}\right)$ between groundwater and lake-water ecosystems (Fig. 2), while pelagic food-web components were indistinguishable with respect to groundwater influence (Fig. 2). Fish species, however, displayed significantly higher $\delta^{15} \mathrm{~N}$ values in benthic and pelagic habitats (Fig. 2). Benthivorous fish in the groundwater habitat displayed a distinct isotopic signature when comparing carbon and sulfur stable isotopes (Fig. 3).

The results of the source partitioning analysis using IsoSource and IsoError gave estimates of the contributions of different sources to the upper trophic level consumers at the groundwater sites (Table 3). The IsoSource mixing model showed reference POM was the dominant dietary component of macroinvertebrates (range $=61$ to $100 \%$ ); groundwater POM (range $=0$ to $13 \%$ ) and benthic producers (range $=0$ to $8 \%$ ) represented smaller contributions. Furthermore, IsoError indicated that benthivorous fish showed a similar pattern, i.e. lake-water macroinvertebrates were the main C source (mean $\pm \mathrm{SE}$ : $84 \pm 25 \%$ ), but groundwater macroinvertebrates also contributed $16 \pm 24 \%$.

\section{DISCUSSION}

Our data suggest that distinct communities comprised of microbial and algal mats, macroinvertebrates, and benthivorous fish incorporate $\mathrm{C}$ and possibly $\mathrm{S}$ derived from venting groundwater in Lake Huron sinkhole ecosystems. The separation of $\delta^{13} \mathrm{C}$ and $\delta^{34} \mathrm{~S}$ values of benthic food-web components between groundwater and reference sites indicates 

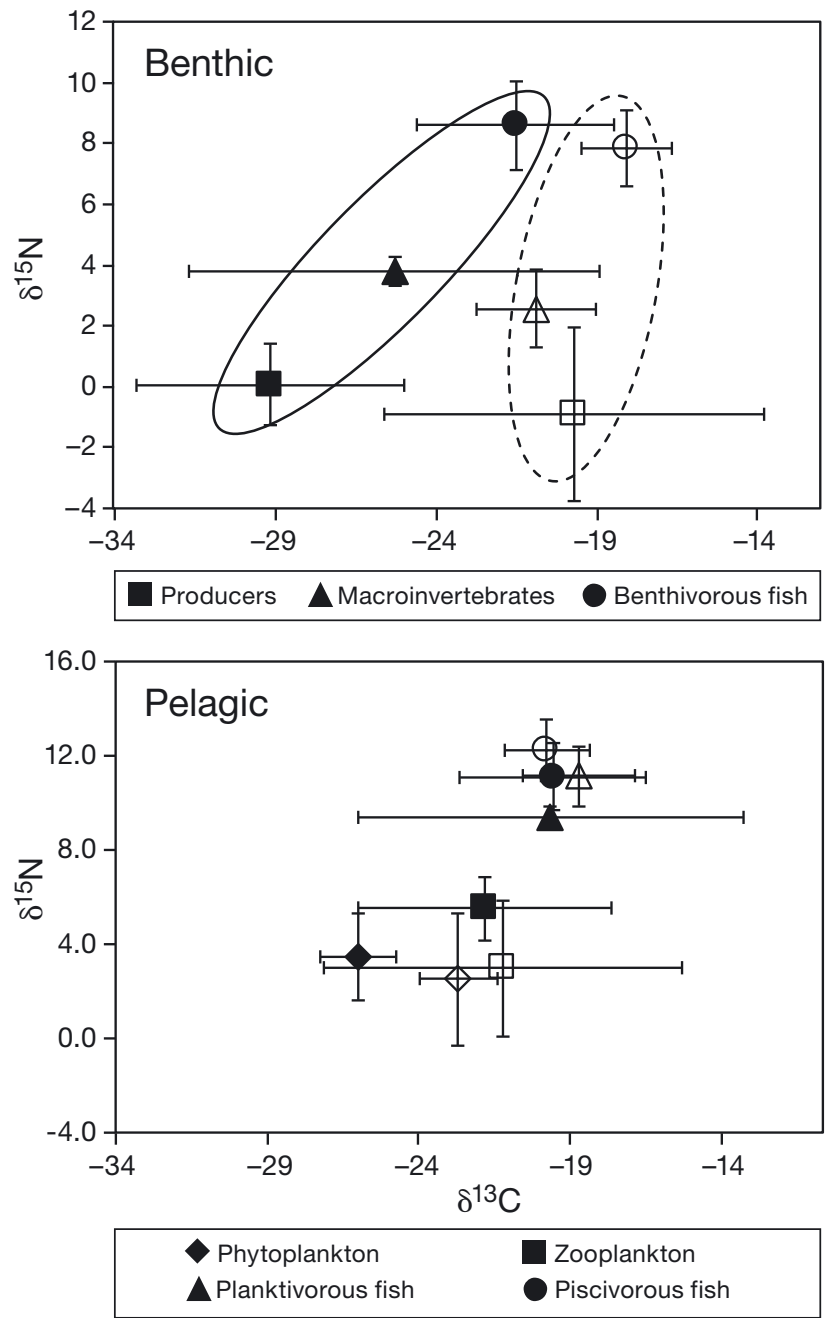

Fig. 2. Stable isotope bi-plots of $\delta^{13} \mathrm{C}$ and $\delta^{15} \mathrm{~N}$ for both benthic and pelagic food webs from groundwater (filled shapes) and lake-water (reference) (open shapes) sites. The ellipses were drawn by the authors for clarity

different nutrient sources. Moreover, the source partitioning analysis shows that small components of both the macroinvertebrate and benthivorous fish $\mathrm{C}$ pool could originate from groundwater-linked production.

Based on the well-separated $\delta^{13} \mathrm{C}$-DIC and $\delta^{34} \mathrm{~S}$-DIS values of groundwater relative to lake water, the former provides a unique source of inorganic $\mathrm{C}$ and $\mathrm{S}$, although the differences were not statistically different due to the small sample size. Based on video and diver observations (Ruberg et al. 2008), the groundwater is denser than the surrounding lake water (due to differences in salinity and temperature), which leads to laminar flow that follows the bathymetry of the system and limits mixing with overlying lake water. We hypothesize that the denser, S-rich groundwater flows out of the vents and disperses across the benthos, bathing this community in nutrient-rich groundwater. This in-

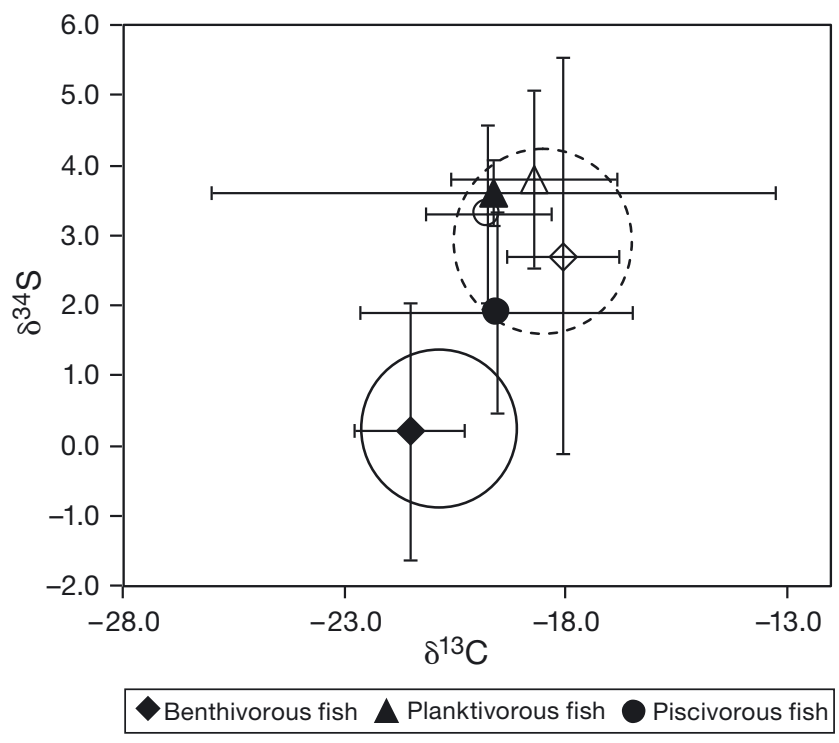

Fig. 3. Stable isotope bi-plot of $\delta^{13} \mathrm{C}$ and $\delta^{34} \mathrm{~S}$ for the 3 trophic groups of fish from groundwater (filled shapes) and lakewater (reference) (open shapes) sites. Circles were drawn by the authors for clarity

organic pool of nutrients appears to be incorporated by the dense organic mats of algae, cyanobacteria, and other microbes during photosynthesis and other alternative metabolic pathways, such as sulfate reduction (Nold et al. 2010a), and during recycling within the mats. In turn, part of this fixed energy is transferred to higher trophic levels in the benthos, which subsidizes the local benthic food web. The plume-like flow of groundwater likely affects the input of $\mathrm{C}$ and $\mathrm{S}$ to different parts of the benthic communities. Theoretically, organisms farther from the groundwater source would show higher $\delta^{13} \mathrm{C}$ values compared to those closer to the source, because the subsidy is reduced. However, this may be partially augmented by nutrient recycling along the spatial continuum.

This hypothesized energy flow path is similar to deep-sea hydrothermal vent habitats, where nutrientrich water creates localized benthic ecosystems based on microbial metabolism (Lonsdale 1977, for a review see Lutz \& Kennish 1993). Furthermore, research on deep-sea hydrothermal vents using stable isotopes has shown that local upper-level communities of consumers can be linked to non-photosynthetic primary producers (Kennicutt et al. 1992, Van Dover 2000, Colaço et al. 2002).

The lake water $\delta^{13} \mathrm{C}$-DIC values are consistent with expectations for lakes of moderate to high $\mathrm{pH}$, where dissolved bicarbonate is the predominant species and in equilibrium with atmospheric $\mathrm{CO}_{2}\left(\delta^{13} \mathrm{C}\right.$ ca. $\left.-8 \%\right)$ (Keough et al. 1998). Relative to lake water, venting groundwater was depleted in $\delta^{13} \mathrm{C}$ by $4 \%$. The lower $\delta^{13} \mathrm{C}$-DIC of the groundwater areas is likely due to $\mathrm{CO}_{2}$ 
Table 3. Calculated contributions of different food sources to benthic macroinvertebrates and benthivorous fish at groundwater sites. Isotope data is from mean values derived from food-web sampling, except for plankton values, which were a mean of both phytoplankton and zooplankton samples from the shallow lake-water, offshore groundwater, and offshore lake-water sites. Increment: increment of increase parameter set as part of the IsoSource program; Tolerance: accepted tolerance value $( \pm)$ from the known value of the mixture of $\delta^{13} \mathrm{C}$ and $\delta^{15} \mathrm{~N}$ values; POM: particulate organic matter, CI: confidence interval

\begin{tabular}{|c|c|c|c|c|c|c|c|}
\hline Trophic compartment & $\begin{array}{l}\text { Increment } \\
(\%)\end{array}$ & $\begin{array}{l}\text { Tolerance } \\
\qquad \% \text { \% })\end{array}$ & Food sources & $\begin{array}{l}\delta^{13} \mathrm{C} \\
(\%)\end{array}$ & $\begin{array}{l}\delta^{15} \mathrm{~N} \\
(\%)\end{array}$ & $\begin{array}{l}\text { Contribution } \\
\text { range }(\%)\end{array}$ & \\
\hline \multirow{7}{*}{$\begin{array}{l}\text { Groundwater macro- } \\
\text { invertebrates }^{\mathrm{a}}\end{array}$} & 1 & 0.5 & & -25.3 & 3.8 & & \\
\hline & & & Groundwater POM & -26.1 & 1.3 & $0-13$ & \\
\hline & & & Lake-water POM & -25.5 & 3.6 & $61-100$ & \\
\hline & & & Groundwater producers & -29.2 & 0.1 & $0-8$ & \\
\hline & & & Lake-water producers & -19.7 & -0.9 & $0-6$ & \\
\hline & & & Plankton & -22.3 & 3.6 & $0-31$ & \\
\hline & & & & & & $\begin{array}{l}\text { \% Contribution } \\
\text { (mean } \pm \mathrm{SE})\end{array}$ & $95 \% \mathrm{CI}$ \\
\hline \multirow{3}{*}{$\begin{array}{l}\text { Groundwater benthi- } \\
\text { vorous fish }\end{array}$} & & & & -21.6 & & & \\
\hline & & & $\begin{array}{c}\text { Groundwater macro- } \\
\text { invertebrates }\end{array}$ & -25.3 & & $16 \pm 24$ & $0-67$ \\
\hline & & & $\begin{array}{l}\text { Lake-water macro- } \\
\text { invertebrates }\end{array}$ & -20.9 & & $84 \pm 25$ & $33-100$ \\
\hline
\end{tabular}

contributions from heterotrophic respiration in the sediments. Respiration of organic $\mathrm{C}$ by heterotrophic bacteria (as well as other groups) results in ${ }^{13} \mathrm{C}$-depleted $\mathrm{CO}_{2}$ that subsequently lowers the $\delta^{13} \mathrm{C}$ value of DIC (Peterson \& Fry 1987, Chapelle \& McMahon 1991, Nascimento et al. 1997, Keough et al. 1998). The importance of respiration-derived $\mathrm{CO}_{2}$ in the DIC pool has been observed in many aquatic systems (Bade et al. 2004), has been experimentally confirmed (Keough et al. 1998), and is evident throughout most of the Silurian-Devonian aquifers of northern Michigan (McIntosh \& Walter 2006).

Although the $\delta^{34} \mathrm{~S}$-DIS data were sparse, it appears that groundwater is highly enriched in ${ }^{34} \mathrm{~S}$ relative to lake water. This is consistent with dissolution of ancient evaporite deposits by venting groundwater (McIntosh \& Walter 2006). In contrast, the single Lake Huron $\delta^{34} \mathrm{~S}$ value better reflects watershed sources of dissolved $\mathrm{SO}_{4}$. We note that in the environment directly influenced by venting groundwater, anoxic bacterial sulfate reduction occurs at depth in the sediments (Nold et al. 2010a), which results in ${ }^{34} \mathrm{~S}$-depleted $\mathrm{H}_{2} \mathrm{~S}$. Subsequent oxidation of the sulfide back to sulfate, both abiotically and by $\mathrm{S}$ oxidizers, largely retains the depleted ${ }^{34} \mathrm{~S}$ value in the newly formed secondary $\mathrm{SO}_{4}$, since fractionation is minimal during sulfide oxidation relative to sulfate reduction (Nakai \& Jensen 1964, Bates et al. 2002). Our data suggest that the predominant pool of fixed $\mathrm{S}$ is derived from the isotopi- cally light secondary $\mathrm{SO}_{4}$ pool that is cycled within the upper mats and sediments and that this fixed $\mathrm{S}$ is then propagated up through vent consumers.

In contrast to the benthos, the input of groundwater does not appear to extend to the pelagic food web, most notably at the offshore site. Most likely, the density differences in the laminar plume of groundwater limit it from mixing with the upper parts of the water column (Ruberg et al. 2008, Biddanda et al. 2009). At the shallow groundwater site, there is not a welldeveloped water column and mixing occurs more rapidly, which is indicated by a greater influence of groundwater on the isotope signature of pelagic foodweb components. At the deep groundwater site, the small volume of groundwater entering the system relative to the surrounding lake water weakens the extent of the influence of groundwater. Our data suggest that phytoplankton, zooplankton and planktivorous fish are not reliant on groundwater-derived $C$, as the $\delta^{13} \mathrm{C}$ values of these trophic levels were not different between groundwater and reference ecosystems. Furthermore, planktivorous and piscivorous fish are more mobile than small, benthic species, which would make them more likely to forage over a wide geographic area, therefore, making groundwater-derived $\mathrm{C}$ a small component of their total dietary intake.

Taken together, the distribution of $\mathrm{C}, \mathrm{N}$, and $\mathrm{S}$ isotopes in the various reservoirs of the sinkhole food web suggest a small but distinct input of groundwater- 
fueled microbial mat production to benthic consumers, such as invertebrates and fish. These conclusions are corroborated by the lower $\delta^{13} \mathrm{C}$-DIC values of groundwater becoming expressed in benthic cyanobacterial mats that in turn, are transferred to benthic invertebrates and fish. The $\delta^{15} \mathrm{~N}$ values shift upwards along this trophic gradient, supporting the trophic linkage between benthic mat production and consumption by resident invertebrates. The limited $\delta^{34} \mathrm{~S}$ data also add to this hypothesis, in that the groundwater influence does not seem to impact the local pelagic fish of the surrounding lake.

Our observations portray a unique benthic ecosystem in which groundwater emerges from the carbonate aquifer, covering the benthos, and supporting a novel sub-ecosystem. Here, benthic macroinvertebrates rely on bacterial mat production as a food source and are, in turn, consumed by benthivorous fish. This zone is low in dissolved oxygen, but rich in inorganic nutrients, which creates ideal conditions for the growth of cyanobacterial mats and algae. However, questions remain from this preliminary study. Most notably, data on the spatial heterogeneity of isotopic inputs and the extent of groundwater influence are lacking and should be included in future studies. Heterogeneous groundwater flow rates have been shown to impact macrophyte biomass (Lodge et al. 1989), so it is plausible that inorganic inputs from groundwater would also affect the isotopic composition of local food-web producers and consumers.

To our knowledge, these data provide the first evidence of benthic communities in the Great Lakes that are partly supported by nutrients from groundwater vents. The possibility of many more vent communities with a rich microbial fauna in other regions of the Great Lakes is quite likely (e.g. Biddanda et al. 2006, Chaudhary et al. 2009), as the entire northern portion of Lake Michigan and Lake Huron are underlain by carbonate bedrock (Grannemann et al. 2000), with a distinct carbonate ridge that bisects Lake Huron from the karst-sinkhole fault complex near Alpena across the lake to southwestern Ontario, Canada. In addition, the Lake Huron basin is surrounded by highly productive littoral zones (Les Cheneaux Islands, Georgian Bay, and Saginaw Bay; Dodge \& Kavetsky 1994) that could be sites of elevated primary production due to inorganic nutrients from groundwater input.

The advent of tracers such as stable isotopes has enabled our ideas about linkages among and within food webs to move from conceptual to quantitative. Recent research in other large lakes has shown the presence of hydrothermal vents and associated ecosystems where the food webs are linked to nutrients in the venting water (De Ronde et al. 2002, Morgan et al. 2003). We emphasize that the areas in Lake Huron are not hydrothermal vents. However, these karst sinkholes may serve a similar role as a concentrated area of microbial activity that is linked to the surrounding benthic macroinvertebrate and fish community. Indeed, karst ecosystems are known to support unique and specialized food webs (Opsahl \& Chanton 2006). Our previous observations of Lake Huron sinkholes have indicated that the distribution of benthic cyanobacterial mats is strictly limited to the zone of groundwater influence and that sinkholes host a diverse community of sinkhole-specific microbes and microinvertebrates (Ruberg et al. 2008, Biddanda et al. 2009, Nold et al. $2010 \mathrm{a}, \mathrm{b})$. The present study demonstrates that these unique benthic ecosystems may act as hot spots of microbial activity, which help support higher trophic levels that are intricately linked to the groundwater flow into the Great Lakes ecosystem.

Acknowledgements. This work was funded by the National Science Foundation (NSF-MCB 0603944 to B.A.B.), Grand Valley State University, and the Michigan Space Grant Consortium (to T.G.S.). We are grateful to S. Kendall, E. Strickler, S. Ruberg, and R. Green, and the dive staff of the NOAA Thunder Bay National Marine Sanctuary for field assistance. Thanks are also due to L. Clyburn and the staff and sea cadets on board Noble Odyssey Foundation's 'Pride of Michigan' for help with field sampling and dive operations. D. Fielder of the Michigan Department of Natural Resources assisted with sampling advice for fish. N. Ostrom, P. Ostrom, H. Gandhi, and C. Cook provided valuable insight into stable isotope analyses. Peerreview of earlier versions of this manuscript by graduate students (K. Thomas, J. DeBoer), faculty (N. MacDonald, R. Rediske, and M. Luttenton) and anonymous Aquatic Biology reviewers helped in making improvements. The use of any trade, product, or firm names is for descriptive purposes only and does not imply endorsement by the US government.

\section{LITERATURE CITED}

APHA (American Public Health Association) (1996) Standard methods for the examination of water and wastewater. APHA, New York, NY

Atekwana EA, Krishnamurthy RV (1998) Seasonal variations of dissolved inorganic carbon and $\delta^{13} \mathrm{C}$ of surface waters: application of a modified gas evolution technique. J Hydrol (Amst) 205:265-278

> Bade DL, Carpenter SR, Cole JJ, Hanson PC, Hesslein RH (2004) Controls of $\delta^{13} \mathrm{C}$-DIC in lakes: geochemistry, lake metabolism, and morphometry. Limnol Oceanogr 49: $1160-1172$

Basterretxea G, Tovar-Sanchez A, Beck AJ, Masqué P and others (2010) Submarine groundwater discharge to the coastal environment of a Mediterranean island (Majorca, Spain): ecosystem and biogeochemical significance. Ecosystems 13:629-643

Bates AL, Orem WH, Harvey JW, Spiker EC (2002) Tracing sources of sulfur in the Florida Everglades. J Environ Qual 31:287-299

> Biddanda BA, Coleman DF, Johengen TH, Ruberg SA and others (2006) Exploration of a submerged sinkhole ecosystem in Lake Huron. Ecosystems 9:828-842 
Biddanda BA, Nold SC, Ruberg SA, Kendall ST, Sanders TG, Gray JJ (2009) Great Lakes sinkholes: a microbiogeochemical frontier. Eos Trans AGU 90:61-62

Black TJ (1983) Selected views of the tectonics, structure and karst in Northern Lower Michigan, Michigan. In: Kimmel RA (ed) Tectonics, structure and karst in Northern Lower Michigan. Proc Michigan Basin Geological Society Field Conf, Lansing, MI, p 11-35

Brock TD, Lee DR, Janes D, Winek D (1982) Groundwater seepage as a nutrient source to a drainage lake; Lake Mendota, Wisconsin. Water Res 16:1255-1263

Burnett WC, Bokuniewicz H, Huettel M, Moore WS, Taniguchi M (2003) Groundwater and pore water inputs to the coastal zone. Biogeochemistry 66:3-33

Capone DG, Bautista MF (1985) A groundwater source of nitrate in nearshore marine sediments. Nature 313:214-216

Carabel S, Godínez-Domínguez E, Verísimo P, Fernández L, Freire J (2006) An assessment of sample processing methods for stable isotope analyses of marine food webs. J Exp Mar Biol Ecol 336:254-261

> Chapelle FH, McMahon PB (1991) Geochemistry of dissolved inorganic carbon in a coastal plain aquifer. 1. Sulfate from confining beds as an oxidant in microbial $\mathrm{CO}_{2}$ production. J Hydrol 127:85-108

> Chaudhary A, Haack SK, Duris JW, Marsh TL (2009) Bacterial and archaeal phylogenetic diversity of a cold sulfurrich spring on the shoreline of Lake Erie, Michigan. Appl Environ Microbiol 75:5025-5036

> Church TM (1996) An underground route for the water cycle. Nature 380:579-580

Colaço A, Dehairs F, Desbruyères D (2002) Nutritional relations of deep-sea hydrothermal fields at the Mid-Atlantic Ridge: a stable isotope approach. Deep-Sea Res I 49:395-412

De Ronde CEJ, Stoffers P, Garbe-Schönberg D, Christenson BW and others (2002) Discovery of active hydrothermal venting in Lake Taupo, New Zealand. J Volcanol Geotherm Res 115:257-275

Dodge D, Kavetsky R (1994) Aquatic habitat and wetlands of the Great Lakes. In: Proc of state of the Great Lakes ecosystem conf, July 1994. US Environmental Protection Agency and Environment Canada, Burlington, Ontario

Estep MLF, Vigg S (1985) Stable carbon and nitrogen isotope tracers of trophic dynamics in natural populations and fisheries of the Lahontan Lake system, Nevada. Can J Fish Aquat Sci 42:1712-1719

Ford DC, Williams P (1989) Karst geomorphology and hydrology. Unwin Hyman, London

> Fry B (1988) Food web structure on Georges Bank from stable C, N, and S isotopic compositions. Limnol Oceanogr 33: $1182-1190$

Fry B (1989) Sulfate fertilization and changes in stable sulfur isotopic compositions of lake sediments. In: Rundel PW, Ehleringer JR, Nagy KA (eds) Stable isotopes in ecological research. Springer, New York, NY

Fry B (2006) Stable isotope ecology. Springer, New York, NY

Grannemann NG, Hunt RJ, Nicholas JR, Reilly TE, Winter TC (2000) The importance of ground water in the Great Lakes region. Water-Resources Investigations Report 00-4008. US Geological Survey, Lansing, MI

> Hagerthey SE, Kerfoot WC (1998) Groundwater flow influences the biomass and nutrient ratios of epibenthic algae in a north temperate seepage lake. Limnol Oceanogr 43: 1227-1242

Hamilton SK, Lewis WM Jr, Sippel SJ (1992) Energy sources for aquatic animals in the Orinoco River floodplain: evidence from stable isotopes. Oecologia 89:324-330

Hesslein RH, Capel MJ, Fox DE, Hallard KA (1991) Stable iso- topes of sulfur, carbon, and nitrogen as indicators of trophic level and fish migration in the lower Mackenzie River basin, Canada. Can J Fish Aquat Sci 48:2258-2265

$>$ Hobson KA, Welch HE (1992) Determination of trophic relationships within a high Arctic marine food web using $\delta^{13} \mathrm{C}$ and $\delta^{15} \mathrm{~N}$ analysis. Mar Ecol Prog Ser 84:9-18

Hubbs CL, Lagler KF (2007) Fishes of the Great Lakes Region, rev edn. The University of Michigan Press, Ann Arbor, MI

Jennings JN (1985) Karst geomorphology. Basil Blackwell, New York, NY

> Johannes RE (1980) The ecological significance of submarine discharges of groundwater. Mar Ecol Prog Ser 3:365-373

Jones JI, Waldron S (2003) Combined stable isotope and gut content analysis of food webs in plant-dominated, shallow lakes. Freshw Biol 48:1396-1407

Kennicutt MC II, Burke RA, MacDonald IR, Brooks JM, Denoux GJ, Macko SA (1992) Stable isotope partitioning in seep and vent organisms: chemical and ecological significance. Chem Geol 101:293-310

$>$ Keough JR, Sierszen ME, Hagley CA (1996) Analysis of a Lake Superior coastal food web with stable isotope techniques. Limnol Oceanogr 41:136-146

> Keough JR, Hagley CA, Ruzycki E, Sierszen M (1998) $\delta^{13} \mathrm{C}$ composition of primary producers and role of detritus in a freshwater coastal ecosystem. Limnol Oceanogr 43: 734-740

> Lodge DM, Krabbenhoft DP, Striegl RG (1989) A positive relationship between groundwater velocity and submersed macrophyte biomass in Sparkling Lake, Wisconsin. Limnol Oceanogr 34:235-239

Loeb SL, Goldman CR (1979) Water and nutrient transport via groundwater from Ward Valley into Lake Tahoe. Limnol Oceanogr 24:1146-1154

Lonsdale PF (1977) Clustering of suspension-feeding macrobenthos near abyssal hydrothermal vents at oceanic spreading centers. Deep-Sea Res 24:857-863

Lutz RA, Kennish MJ (1993) Ecology of deep-sea hydrothermal vent communities: a review. Rev Geophys 31: 211-242

McClelland JW, Valiela I, Michener RH (1997) Nitrogenstable isotope signatures in estuarine food webs: a record of increasing urbanization in coastal watersheds. Limnol Oceanogr 42:930-937

McIntosh JC, Walter LM (2006) Paleowaters in SilurianDevonian carbonate aquifers: geochemical evolution of groundwater in the Great Lakes region since the Late Pleistocene. Geochim Cosmochim Acta 70:2454-2479

Moore WS (1996) Large groundwater inputs to coastal waters revealed by ${ }^{226} \mathrm{Ra}$ enrichments. Nature 380:612-614

> Moore WS (2010) The effect of submarine groundwater discharge on the ocean. Annu Rev Mar Sci 2:59-88

> Moore WS, Sarmiento JL, Key RM (2008) Submarine groundwater discharge revealed by ${ }^{228} \mathrm{Ra}$ distribution in the upper Atlantic Ocean. Nat Geosci 1:309-311

Moreau RB (1983) A review of the limnological characteristics of Alpena, Michigan area flowing wells and sinkholes. In: Kimmel RA (ed) Tectonics, structure and karst in Northern Lower Michigan. Proc Michigan Basin Geological Society Field Conf, Lansing, MI, p 91-118

Morgan LA, Shanks WC III, Lovalvo DA, Johnson SY and others (2003) Exploration and discovery in Yellowstone Lake: results from high-resolution sonar imaging, seismic reflection profiling, and submersible studies. J Volcanol Geotherm Res 122:221-242

Nakai N, Jensen JL (1964) The kinetic isotope effect in the bacterial reduction and oxidation of sulfur. Geochim Cosmochim Acta 28:1893-1912 
Nascimento C, Atekwana EA, Krishnamurthy VE (1997) Concentrations and isotope ratios of dissolved inorganic carbon in denitrifying environments. Geophys Res Lett 24: $1511-1514$

Nold SC, Pangborn JP, Zajack H, Kendall S, Rediske R, Biddanda BA (2010a) Benthic bacterial diversity in submerged sinkhole ecosystems. Appl Environ Microbiol 76: $347-351$

Nold SC, Zajack HA, Biddanda BA (2010b) Eukaryal and archaeal diversity in a submerged sinkhole ecosystem influenced by sulfur-rich, hypoxic groundwater. J Gt Lakes Res 36:366-375

Opsahl SP, Chanton JP (2006) Isotopic evidence for methanebased chemosynthesis in the Upper Floridian aquifer food web. Oecologia 150:89-96

Peterson BJ, Fry B (1987) Stable isotopes in ecosystem studies. Annu Rev Ecol Syst 18:293-320

Peterson BJ, Howarth RW (1987) Sulfur, carbon, and nitrogen isotopes used to trace organic matter flow in the salt-marsh estuaries of Sapelo Island, Georgia. Limnol Oceanogr 32: 1195-1213

Peterson BJ, Howarth RW, Garritt RH (1986) Sulfur and carbon isotopes as tracers of salt-marsh organic matter flow. Ecology 67:865-874

Phillips DL, Gregg JW (2001) Uncertainty in source partitioning using stable isotopes. Oecologia 127:171-179

Phillips DL, Gregg JW (2003) Source partitioning using stable

Editorial responsibility: Jonathan Cole,

Milbrook, New York, USA isotopes: coping with too many sources. Oecologia 136: 261-269

Ruberg S, Coleman D, Johengen $\mathrm{T}$, Meadows G, Van Sumeren H, Lang G, Biddanda B (2005) Groundwater plume mapping in a submerged sinkhole in Lake Huron. Mar Technol Soc J 39:65-69

Ruberg S, Kendall ST, Biddanda BA, Black T and others (2008) Observations of the Middle Island sinkhole in Lake Huron - a unique hydrogeologic and glacial creation of 400 million years. Mar Technol Soc J 42:12-21

- Shaw RD, Prepas EE (1990) Groundwater-lake interactions. II. Nearshore seepage patterns and the contribution of ground water to lakes in central Alberta. J Hydrol 119: 121-126

Slomp CP, Van Cappellan P (2004) Nutrient inputs to the coastal ocean through submarine groundwater discharge: controls and potential impact. J Hydrol 295:64-86

Sweeting CJ, Polunin NVC, Jennings S (2006) Effects of chemical lipid extraction and arithmetic lipid correction on stable isotope ratios of fish tissues. Rapid Commun Mass 20:595-601

Valiela I, Costa J, Foreman K, Teal JM, Howes B, Aubrey D (1990) Transport of groundwater-borne nutrients from watersheds and their effects on coastal waters. Biogeochemistry 10:177-197

Van Dover CL (2000) The ecology of deep-sea hydrothermal vents. Princeton University Press, Princeton, NJ

Submitted: November 2, 2009; Accepted: December 27, 2010 Proofs received from author(s): February 16, 2011 